Bryant University

Bryant Digital Repository

\title{
Listening to Life's Lessons: Using music Lyrics and Poetry to Face Issues of Aging in the Classroom
}

Nanci Weinberger

Bryant University

Follow this and additional works at: https://digitalcommons.bryant.edu/apjou

\section{Recommended Citation}

Weinberger, Nanci, "Listening to Life's Lessons: Using music Lyrics and Poetry to Face Issues of Aging in the Classroom" (2008). Applied Psychology Journal Articles. Paper 38.

https://digitalcommons.bryant.edu/apjou/38

This Article is brought to you for free and open access by the Applied Psychology Faculty Publications and Research at Bryant Digital Repository. It has been accepted for inclusion in Applied Psychology Journal Articles by an authorized administrator of Bryant Digital Repository. For more information, please contact dcommons@bryant.edu. 
This article was downloaded by: [Weinberger, Nanci]

On: 10 September 2008

Access details: Access Details: [subscription number 902342405]

Publisher Routledge

Informa Ltd Registered in England and Wales Registered Number: 1072954 Registered office: Mortimer House, 37-41 Mortimer Street, London W1T 3JH, UK

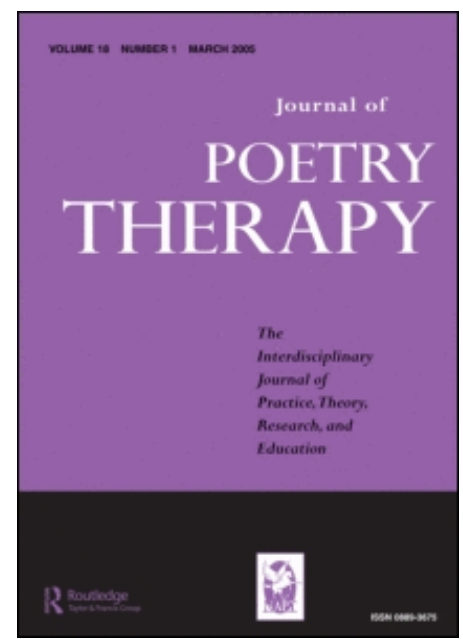

Journal of Poetry Therapy

Publication details, including instructions for authors and subscription information:

http://www.informaworld.com/smpp/title content=t713693744

\section{Listening to life's lessons: Using music lyrics and poetry to face issues of aging} in the classroom

Nanci Weinberger a

a Department of Applied Psychology, Bryant University, Smithfield, RI, USA

Online Publication Date: 01 September 2008

To cite this Article Weinberger, Nanci(2008)'Listening to life's lessons: Using music lyrics and poetry to face issues of aging in the classroom',Journal of Poetry Therapy,21:3,135 - 144

To link to this Article: DOI: $10.1080 / 08893670802338239$

URL: http://dx.doi.org/10.1080/08893670802338239

\section{PLEASE SCROLL DOWN FOR ARTICLE}

Full terms and conditions of use: http://www.informaworld.com/terms-and-conditions-of-access.pdf

This article may be used for research, teaching and private study purposes. Any substantial or systematic reproduction, re-distribution, re-selling, loan or sub-licensing, systematic supply or distribution in any form to anyone is expressly forbidden.

The publisher does not give any warranty express or implied or make any representation that the contents will be complete or accurate or up to date. The accuracy of any instructions, formulae and drug doses should be independently verified with primary sources. The publisher shall not be liable for any loss, actions, claims, proceedings, demand or costs or damages whatsoever or howsoever caused arising directly or indirectly in connection with or arising out of the use of this material. 


\title{
Listening to life's lessons: Using music lyrics and poetry to face issues of aging in the classroom
}

\author{
Nanci Weinberger \\ Department of Applied Psychology, Bryant University, 1150 Douglas Pike, Smithfield, RI \\ 02917, USA
}

The use of poetry and music in college courses on aging is discussed. The format can help instructors reach their students in new ways. Poetry and music can be used to engage students in material that may be emotionally charged. In addition, poetry and music can be used to help students confront stereotypes about the elderly.

Keywords Aging; college; education; gerontology; music; poetry

"I ask them to take a poem

And hold it up to the light

like a color slide"

-Billy Collins (2004), Introduction to Poetry, 16

The examination of challenging concepts in a college classroom setting can be pursued in a number of ways. Creative approaches are especially useful in the instances when a course frequently introduces emotionally charged concepts such as courses in abnormal psychology, developmental disabilities, adult development and aging and gerontology. Each teacher develops classroom techniques that fit not only the content of the course but their interests and teaching style. Among the many approaches that instructors use, the inclusion of music and poetry will be discussed here with special attention to issues related to aging.

Many techniques to enrich lectures and engage students have been successfully introduced for a wide range of college classes. Instructors share full-length films or film segments (Green, 2003; Paddock, Terranova \& Giles, 2001), use humor (Powers, 2005), or storytelling (Green, 2004), or share children's picture books

^Corresponding author. Tel: 401-232-6000. Fax: 401-232-6319. Email: nweinber@bryant.edu 
(Meyerson, 2006). Other instructors have discussed using music and poetry as well. Several instructors in the social sciences have reported playing music and music videos in a wide range of courses (Daehler \& Miller, 2004; Leck, 2006; Deluga, Personal Communication, July 12, 2007; Morrison, Personal Communication, July $11,2007)$. They use music to build rapport, to orient students to key concepts and to improve intellectual access to challenging theoretical ideas. Also poetry writing and related exercises have been used to promote empathetic responses toward individuals with mental illness and other problems discussed in abnormal psychology and social work courses (Conner-Greene, Young, Paul, \& Murdoch, 2005; Furman, 2007).

Additional ideas have been presented for college classes that focus on the elderly. For example, instructors have brought in theatre techniques, such as having an elderly character give a life review during a dramatic performance in gerontology courses (MacRae \& Pardue, 2007; Schmidtke, 2000). Student drawings of the elderly have also been used in class discussions to confront students' preconceived notions of the elderly (Barrett \& Cantwell, 2007). Other instructors have students imagine themselves at an older age and then create displays with a range of visual images to represent their perceptions (Masters \& Holley, 2006). A common goal for these varied techniques has been to help college students see the elderly more clearly than they had in the past.

There are settings beyond the college classroom that also necessitate facing some of the challenging issues of aging. Clearly, nursing home residents face a host of concerns including maintaining optimal levels of independence. Art therapists use a range of creative techniques to support resident well-being including discussing folk tales and their connections to the residents' lives and their concerns (Warner, 2006). In addition, poetry has been used as a form of therapy in groups for individuals with Alzheimer's disease (Weinberger \& Russo, 2005). For example, poetry therapists have used the poem, Where I'm From, by George Ella Lyon (1999), that describes a woman's personal history in the context of the broader culture of her times. Group members can attend to and discuss the geographic, historical and psychological origins of the character in the poem. Group members are asked to reflect on their own origins and to write about their lives. This gives the writers an opportunity to recall notable aspects of their lives and creatively express themselves. Their creations are tangible gifts that can be shared with family members about their lives, providing opportunities for greater understanding and connection.

There may not always be enough time in a college class to have students write their own poems or lyrics. An advantage of having the instructor present music and poetry in a class setting is that it can be easily introduced without taking up as much time as showing a film or giving a dramatic presentation. In addition, students may find music and poetry to be relatively accessible to them as they think about the key issues. Music in particular is familiar to students and they may have more of a sense of freedom to discuss it as compared with other representations of information such as empirical research reports. The same freedom requires instructor flexibility because the songs and poems can easily evoke themes that may not have been expected by the instructor. For example, Patty Griffin's (2002) song, Making Pies, often brings to mind memories about family members making pies and how 
comforting this and other family traditions are. Even though the song is not about this family tradition, the song can open the door to the meaning of family traditions and family roles. While open discussions may be challenging to facilitate, they can also support certain academic goals.

A primary pedagogical goal for instructors is to have their students gain a deeper understanding of important concepts. With respect to courses dealing with aging, the lives of individuals being studied may differ significantly from the lives of the traditional student body. Thus, instructors may seek to provide a realistic mix of models of how individuals face aging. This may increase understanding of the issues and potentially increase student empathy for older adults. In addition, in classes that are primarily lecture-based, poetry and music can facilitate student engagement in classroom discussion by changing the way the material is presented. Hearing a poem or a song changes the auditory experience. However, directly incorporating music and poetry as part of the class is only one way to use these resources. Some instructors choose to play songs prior to class (Daehler \& Miller, 2004). For example, Morrison uses music to mark the beginning of a class period and Deluga shows music videos before and after class solely to break the ice and build rapport with students. Other instructors use class time to display lyrics and discuss the relevant themes and have assigned students to find songs of their own that demonstrate the concepts under discussion (Leck, 2006; Weinberger \& Russo, 2005; Weinrauch, 2005). Increasingly, internet options include audio files that can be used in class (e.g., The Writer's Almanac at http://writersalmanac.publicradio.org/ and the Academy of American Poets at http://poets.org) and video segments. For example, the animated poem Forgetfulness is read by the poet Billy Collins on the YouTube website. If an instructor wants their students to closely attend to the words, it is recommended that students be able to read along when the poem is read or the song is being played. This can be done by either projecting the words on a large screen or providing a handout with the words. While a handout requires more resources, it allows the students to take the words and the source information with them. This is especially useful if the material connects to an assignment or an exam.

Some of the challenging issues that are addressed in a class on aging include sensory loss, memory loss, physical decline, morbidity and mortality risk factors as well as death, dying and bereavement. While most of the course may focus on research and supporting statistics related to aging individuals, spending time listening to music and poetry allows students a chance to intellectually and emotionally connect with these experiences. Each poem or song may evoke one or more nonmutually exclusive themes related to the course. A sampling of poems and songs that connect to a range of topics are presented in Tables 1 and 2, respectively. The collection reflects the author's own interests in music and poetry and changes with student and colleague input. Instructors can begin to cull poems and music lyrics from their own collections. For example, a marketing instructor uses his interest in show tunes to find songs that best fit his course material (Weinrauch, 2005). As an instructor begins to use these materials in class students are reminded of their own collections (more often musical selections than poems) and can be encouraged to share them with their instructors. In addition, colleagues are also a 
TABLE 1. A selection of poems that address issues of aging.

\begin{tabular}{|c|c|c|c|c|}
\hline Theme & Poem title & Poet & Source & Sample line \\
\hline $\begin{array}{l}\text { Coping; } \\
\text { bereavement }\end{array}$ & Elegy & May Sarton & $\begin{array}{l}\text { Coming into Eighty } \\
\text { (1994) } \\
\text { W.W. Norton \& } \\
\text { Company }\end{array}$ & $\begin{array}{l}\text { You will always be walking } \\
\text { Down the grassy path }\end{array}$ \\
\hline Coping; dying & $\begin{array}{l}\text { After the long } \\
\text { enduring }\end{array}$ & May Sarton & $\begin{array}{l}\text { Coming into Eighty } \\
\text { (1994) } \\
\text { W.W. Norton \& } \\
\text { Company }\end{array}$ & You who noticed everything \\
\hline $\begin{array}{l}\text { Coping; } \\
\text { physical } \\
\text { decline }\end{array}$ & Otherwise & Jane Kenyon & $\begin{array}{l}\text { Otherwise (1996) } \\
\text { Graywolf } \\
\text { Press }\end{array}$ & $\begin{array}{l}\text { With wide open eyes } \\
\text { I got out of bed on two } \\
\text { strong legs. It might have } \\
\text { been otherwise. }\end{array}$ \\
\hline Death & $\begin{array}{l}\text { Contemplating } \\
\text { death }\end{array}$ & $\begin{array}{l}\text { Ramson } \\
\text { Lomatewama }\end{array}$ & $\begin{array}{l}\text { Silent Winds } \\
\text { (1983) Badger } \\
\text { Claw Press }\end{array}$ & "Be patient" \\
\hline & & & & $\begin{array}{l}\text { The time will come for you } \\
\text { to make the journey }\end{array}$ \\
\hline Death & $\begin{array}{l}\text { Poem for my } \\
\text { 70th birthday }\end{array}$ & $\begin{array}{l}\text { Charles } \\
\text { Bukowski }\end{array}$ & $\begin{array}{l}\text { Slowing toward } \\
\text { Nirvana } \\
(2005)\end{array}$ & $\begin{array}{l}\text { I think of the young man } \\
\text { who wanted so badly to die } \\
\text { and of the old man now } \\
\text { who doesn't care whether } \\
\text { he does or doesn't }\end{array}$ \\
\hline $\begin{array}{l}\text { Dying \& } \\
\text { personal } \\
\text { history }\end{array}$ & $\begin{array}{l}\text { Do not go } \\
\text { gentle } \\
\text { into that good } \\
\text { night }\end{array}$ & $\begin{array}{l}\text { Dylan } \\
\text { Thomas }\end{array}$ & $\begin{array}{l}\text { Harper Collins } \\
\text { The Poems of } \\
\text { Dylan Thomas } \\
\text { (1971) New } \\
\text { Directions } \\
\text { Publishing }\end{array}$ & $\begin{array}{l}\text { Old age should burn and } \\
\text { rave at close of day; Rage, } \\
\text { rage against the dying of } \\
\text { the light }\end{array}$ \\
\hline Loss & Affirmation & Donald Hall & $\begin{array}{l}\text { The Painted Bed } \\
(2002)\end{array}$ & $\begin{array}{l}\text { Even when we are young, } \\
\text { we glimpse it sometimes, } \\
\text { and nod our heads when a } \\
\text { grandfather dies }\end{array}$ \\
\hline & & & $\begin{array}{l}\text { Houghton Mifflin } \\
\text { Company }\end{array}$ & \\
\hline Loss & $\begin{array}{l}\text { In view of the } \\
\text { fact }\end{array}$ & A.R. Ammons & $\begin{array}{l}\text { Bosh and } \\
\text { Flapdoodle (2005) } \\
\text { W.W. Norton \& } \\
\text { Company }\end{array}$ & $\begin{array}{l}\text {...at the same time we are } \\
\text { getting used to so many } \\
\text { leaving, we are hanging on } \\
\text { with a grip to the ones left }\end{array}$ \\
\hline Loss & Legacies & $\begin{array}{l}\text { Nikki } \\
\text { Giovanni }\end{array}$ & $\begin{array}{l}\text { The Women and } \\
\text { the Men (1975) } \\
\text { William Morrow \& } \\
\text { Company }\end{array}$ & $\begin{array}{l}\text { and neither of them ever } \\
\text { said what they meant and I } \\
\text { guess nobody ever does }\end{array}$ \\
\hline Memory loss & Forgetfulness & Billy Collins & $\begin{array}{l}\text { Sailing Alone } \\
\text { around the Room } \\
\text { (2001) Random } \\
\text { House }\end{array}$ & $\begin{array}{l}\text {... the memories you used } \\
\text { to harbor decided to retire to } \\
\text { the southern hemisphere of } \\
\text { the brain, to a little fishing } \\
\text { village where there are no } \\
\text { phones }\end{array}$ \\
\hline
\end{tabular}


TABLE 1 (Continued)

\begin{tabular}{|c|c|c|c|c|}
\hline Theme & Poem title & Poet & Source & Sample line \\
\hline Personal history & $\begin{array}{l}\text { Where I'm } \\
\text { from }\end{array}$ & $\begin{array}{l}\text { George Ella } \\
\text { Lyon }\end{array}$ & $\begin{array}{l}\text { Where I'm From } \\
\text { (1999) }\end{array}$ & $\begin{array}{l}\text { I am from clothespins, from } \\
\text { Clorox and carbon- } \\
\text { tetrachloride }\end{array}$ \\
\hline Physical decline & $\begin{array}{l}\text { Friend or } \\
\text { enemy }\end{array}$ & May Sarton & $\begin{array}{l}\text { Absey \& Company } \\
\text { Coming into Eighty } \\
\text { (1994) W.W. } \\
\text { Norton \& } \\
\text { Company }\end{array}$ & $\begin{array}{l}\text { I can look at my body as an } \\
\text { old friend }\end{array}$ \\
\hline Physical decline & Getting dressed & May Sarton & $\begin{array}{l}\text { Coming into Eighty } \\
(1994) \text { W.W. } \\
\text { Norton \& } \\
\text { Company }\end{array}$ & $\begin{array}{l}\text { Pulling on a sweater I get } \\
\text { lost inside it }\end{array}$ \\
\hline $\begin{array}{l}\text { Physical } \\
\text { decline; } \\
\text { continuity }\end{array}$ & Somebody else & $\begin{array}{l}\text { Charles } \\
\text { Bukowski }\end{array}$ & $\begin{array}{l}\text { Slowing toward } \\
\text { Nirvana (2005) } \\
\text { Harper Collins }\end{array}$ & $\begin{array}{l}\text { Who is that ugly old man? } \\
\text { he frightens me }\end{array}$ \\
\hline Successful aging & The way it is & $\begin{array}{l}\text { William } \\
\text { Stafford }\end{array}$ & $\begin{array}{l}\text { The Way It Is } \\
\text { (1998) Graywolf } \\
\text { Press }\end{array}$ & $\begin{array}{l}\text { There is a thread you } \\
\text { follow. It goes among things } \\
\text { that change. But it doesn't } \\
\text { change. }\end{array}$ \\
\hline Successful aging & That was I & Ted Kooser & $\begin{array}{l}\text { Delights \& } \\
\text { Shadows (2004) } \\
\text { Copper Canyon } \\
\text { Press }\end{array}$ & $\begin{array}{l}\text { Instead I was looking with } \\
\text { hope to a grapevine draped } \\
\text { over a fence in a neighbor- } \\
\text { ing yard, and knowing that } \\
\text { I could hold on. }\end{array}$ \\
\hline $\begin{array}{l}\text { Successful } \\
\text { aging; physi- } \\
\text { cal } \\
\text { decline }\end{array}$ & On aging & $\begin{array}{l}\text { Maya } \\
\text { Angelou }\end{array}$ & $\begin{array}{l}\text { And Still I Rise } \\
\text { (1978) Random } \\
\text { House }\end{array}$ & $\begin{array}{l}\text { When you see me sitting } \\
\text { quietly, Like a sack left on } \\
\text { the shelf }\end{array}$ \\
\hline $\begin{array}{l}\text { Successful } \\
\text { aging; death }\end{array}$ & $\begin{array}{l}\text { Coming into } \\
\text { eighty }\end{array}$ & May Sarton & $\begin{array}{l}\text { Coming into Eighty } \\
(1994) \text { W.W. } \\
\text { Norton \& } \\
\text { Company }\end{array}$ & $\begin{array}{l}\text { Through time, travail and } \\
\text { triumph, Eighty years Of } \\
\text { learning what to be And } \\
\text { how to become it. }\end{array}$ \\
\hline
\end{tabular}

good resource for making suggestions. Poetry anthologies on core themes can be particularly helpful as well. A recent review on poetry anthologies dealing with grief and bereavement is a useful resource to instructors searching for these specific types of poems (Bowman, 2007). There are excellent web-searching options as well, including www.poetryfoundation.org/ and www.poets.org/ for poems and www. metrolyrics.com/ for lyrics.

One of the most challenging units discussed in a course on aging is death and dying. It is not surprising that there is a rich collection of poetry and songs that address death and dying. One well-known example is Dylan Thomas's (1951/71) poem, Do not go gentle into that good night. In this poem the reader hears a son's pleading for his father to fight his imminent death. The reader is exposed to the raw emotions and desires of someone witnessing a loved one as he is dying. A different perspective of someone witnessing a loved one dying is presented by May Sarton 
TABLE 2. A selection of songs that address issues of aging.

\begin{tabular}{|c|c|c|c|c|c|}
\hline Theme & Song title & Performer & Writer & $\begin{array}{c}\text { Album \& } \\
\text { copyright } \\
\text { owner }\end{array}$ & Sample lyrics \\
\hline Bereavement & $\begin{array}{l}\text { Don't know } \\
\text { why }\end{array}$ & Yoko Ono & Yoko Ono & $\begin{array}{l}\text { Seasons of } \\
\text { Glass }\end{array}$ & $\begin{array}{l}\text { My body is so } \\
\text { empty, the world is } \\
\text { so empty without } \\
\text { you }\end{array}$ \\
\hline \multirow[t]{2}{*}{ Coping } & Valley of pain & Bonnie Raitt & $\begin{array}{l}\text { Allen } \\
\text { Shamblin \& } \\
\text { Gavin } \\
\text { Hodgson }\end{array}$ & $\begin{array}{l}\text { Ryoko Disc } \\
\text { Silver Lining }\end{array}$ & $\begin{array}{l}\text { Don't let the dark- } \\
\text { ness drive me insane } \\
\text { while I'm walking } \\
\text { through the valley of } \\
\text { pain }\end{array}$ \\
\hline & & & & $\begin{array}{l}\text { River Oaks } \\
\text { Music/Maybe } \\
\text { I Can Music } \\
\text { and } \\
\text { Rollywood } \\
\text { Music/Built } \\
\text { On Rock } \\
\text { Music }\end{array}$ & \\
\hline $\begin{array}{l}\text { Coping; } \\
\text { personal } \\
\text { history }\end{array}$ & Making pies & Patty Griffin & Patty Griffin & 1,000 Kisses & $\begin{array}{l}\text { You could cry or die } \\
\text { or just make pies all } \\
\text { day }\end{array}$ \\
\hline \multirow[t]{2}{*}{$\begin{array}{l}\text { Coping; } \\
\text { bereavement }\end{array}$} & $\begin{array}{l}\text { Wanting } \\
\text { memories }\end{array}$ & $\begin{array}{l}\text { Sweet } \\
\text { Honey in the } \\
\text { Rock }\end{array}$ & $\begin{array}{l}\text { Ysaye Maria } \\
\text { Barnwell }\end{array}$ & $\begin{array}{l}\text { ATO Records } \\
\text { Still on the } \\
\text { Journey }\end{array}$ & $\begin{array}{l}\text { I am sitting here } \\
\text { wanting memories to } \\
\text { teach me }\end{array}$ \\
\hline & & & & $\begin{array}{l}\text { Barnwell’s } \\
\text { Notes }\end{array}$ & \\
\hline $\begin{array}{l}\text { Coping; } \\
\text { support }\end{array}$ & Lean on me & $\begin{array}{l}\text { Eric Bibb, } \\
\text { Rory Block } \\
\text { \& Maria } \\
\text { Muldaur }\end{array}$ & Bill Withers & $\begin{array}{l}\text { Sisters \& } \\
\text { Brothers }\end{array}$ & $\begin{array}{l}\text { Lean on me, when } \\
\text { you're not strong }\end{array}$ \\
\hline $\begin{array}{l}\text { Coping; } \\
\text { support }\end{array}$ & $\begin{array}{l}\text { In my time of } \\
\text { need }\end{array}$ & Joan Baez & $\begin{array}{l}\text { Ryan } \\
\text { Anderson }\end{array}$ & $\begin{array}{l}\text { Interior Music } \\
\text { Dark Chords } \\
\text { on a Big } \\
\text { Guitar } \\
\text { Barland } \\
\text { Music }\end{array}$ & $\begin{array}{l}\text { Cause I will come } \\
\text { for you when my } \\
\text { days are through }\end{array}$ \\
\hline $\begin{array}{l}\text { Death \& } \\
\quad \text { relationships }\end{array}$ & $\begin{array}{l}\text { Long ride } \\
\text { home }\end{array}$ & Patty Griffin & Patty Griffin & 1,000 Kisses & $\begin{array}{l}\text { Forty years of things } \\
\text { you say you wish } \\
\text { you never said }\end{array}$ \\
\hline $\begin{array}{l}\text { Dying \& } \\
\text { personal } \\
\text { history }\end{array}$ & Lake Charles & $\begin{array}{l}\text { Lucinda } \\
\text { Williams }\end{array}$ & $\begin{array}{l}\text { Lucinda } \\
\text { Williams }\end{array}$ & $\begin{array}{l}\text { ATO Records } \\
\text { Car Wheels } \\
\text { on } \\
\text { a Gravel Road } \\
\text { Mercury } \\
\text { Records }\end{array}$ & $\begin{array}{l}\text { Did an angel } \\
\text { whisper in your ear? }\end{array}$ \\
\hline
\end{tabular}


TABle 2 (Continued)

\begin{tabular}{|c|c|c|c|c|c|}
\hline Theme & Song title & Performer & Writer & $\begin{array}{c}\text { Album \& } \\
\text { copyright } \\
\text { owner }\end{array}$ & Sample lyrics \\
\hline Life cycle & When I'm 64 & The Beatles & $\begin{array}{l}\text { Paul } \\
\text { McCartney } \\
\text { \& John } \\
\text { Lennon }\end{array}$ & $\begin{array}{l}\text { Sgt. Pepper's } \\
\text { Lonely Hearts } \\
\text { Club Band }\end{array}$ & $\begin{array}{l}\text { Doing the garden, } \\
\text { digging the weeds, } \\
\text { who could ask for } \\
\text { more? }\end{array}$ \\
\hline Life cycle & Nick of time & Bonnie Raitt & Bonnie Raitt & Nick of Time & $\begin{array}{l}\text { I see my folks, } \\
\text { they're getting old, I } \\
\text { watch their bodies } \\
\text { change }\end{array}$ \\
\hline Life cycle & $\begin{array}{l}\text { I know what } \\
\text { love is }\end{array}$ & Don White & Don White & $\begin{array}{l}\text { Lyric Moon } \\
\text { recordings }\end{array}$ & $\begin{array}{l}\text { They are sixty and } \\
\text { their history spans } \\
\text { forty odd years }\end{array}$ \\
\hline Life cycle & $\begin{array}{l}\text { The circle } \\
\text { game }\end{array}$ & $\begin{array}{l}\text { Joni } \\
\text { Mitchell }\end{array}$ & Joni Mitchell & $\begin{array}{l}\text { Ladies of the } \\
\text { Canyon } \\
\text { Siquomb } \\
\text { Publishing } \\
\text { Company }\end{array}$ & $\begin{array}{l}\text { We're captive on the } \\
\text { carousel of time }\end{array}$ \\
\hline $\begin{array}{l}\text { Life cycle; } \\
\text { bereavement }\end{array}$ & If I could & $\begin{array}{l}\text { Jack } \\
\text { Johnson }\end{array}$ & Jack Johnson & $\begin{array}{l}\text { In Between } \\
\text { Dreams } \\
\text { Brushfire } \\
\text { Records }\end{array}$ & $\begin{array}{l}\text { New life makes } \\
\text { losing life easier to } \\
\text { understand }\end{array}$ \\
\hline $\begin{array}{r}\text { Life cycle; } \\
\text { Support }\end{array}$ & $\begin{array}{l}\text { I will follow } \\
\text { you into the } \\
\text { dark }\end{array}$ & $\begin{array}{l}\text { Death Cab } \\
\text { for Cutie }\end{array}$ & $\begin{array}{l}\text { Benjamin } \\
\text { Gibbard }\end{array}$ & $\begin{array}{l}\text { Atlantic } \\
\text { Records }\end{array}$ & $\begin{array}{l}\text { You and me have } \\
\text { seen everything to } \\
\text { see }\end{array}$ \\
\hline Memories & $\begin{array}{l}\text { Precious } \\
\text { memories }\end{array}$ & Bob Dylan & Bob Dylan & $\begin{array}{l}\text { Knocked Out } \\
\text { Loaded } \\
\text { Special Rider } \\
\text { Music }\end{array}$ & $\begin{array}{l}\text { In the stillness of the } \\
\text { midnight, Precious } \\
\text { sacred scenes unfold }\end{array}$ \\
\hline $\begin{array}{l}\text { Personal } \\
\text { history; } \\
\text { continuity }\end{array}$ & 75 Septembers & $\begin{array}{l}\text { Cheryl } \\
\text { Wheeler }\end{array}$ & $\begin{array}{l}\text { Cheryl } \\
\text { Wheeler }\end{array}$ & $\begin{array}{l}\text { Penrod and } \\
\text { Higgins } \\
\text { Music/ } \\
\text { Amachrist } \\
\text { Music ACF } \\
\text { Music Group }\end{array}$ & $\begin{array}{l}\text { Are you more } \\
\text { amazed at how } \\
\text { things change or } \\
\text { how they stay the } \\
\text { same? }\end{array}$ \\
\hline
\end{tabular}


TABLE 2 (Continued)

\begin{tabular}{|c|c|c|c|c|c|}
\hline Theme & Song title & Performer & Writer & $\begin{array}{c}\text { Album \& } \\
\text { copyright } \\
\text { owner }\end{array}$ & Sample lyrics \\
\hline $\begin{array}{l}\text { Successful } \\
\text { aging }\end{array}$ & $\begin{array}{l}\text { Thanksgiving } \\
\text { Eve }\end{array}$ & Bob Franke & Bob Franke & $\begin{array}{l}\text { The Other } \\
\text { Evening in } \\
\text { Chicago } \\
\text { Flying Fish }\end{array}$ & $\begin{array}{l}\text { But love til you've } \\
\text { loved it away }\end{array}$ \\
\hline
\end{tabular}

(1994) in her poem, After the long enduring, about her friend's painful decline. In this poem the singular insight of the friend in spite of his deep suffering and decline is highlighted. The potential for one to continue to be influenced by someone else who has died is elegantly sung about in Wanting memories by Sweet Honey in the Rock (1993), "I thought you were gone, But now I know you're with me You are the voice that whispers All I need to hear." One of the lessons to be learned in a unit on death and dying is that there is no single correct way to experience this part of life. Providing a variety of voices from music and poetry can potentially help students accept such diversity of experience.

Addressing our stereotypes about the elderly and the aging process is also likely to be included in one or more class discussions. Negative attitudes about the elderly are widespread in American society (Nelson, 2005). Ted Kooser's (2004) poem, That was I, reveals some of our implicit assumptions about the elderly and how our assumptions are not always correct. Kooser leads the reader to expect the elderly character in his poem to be fixated on death ("And that was I you spotted that evening just before dark, in a weedy cemetery west of Staplehurst, down on one knee as if trying to make out the name on a stone”, p. 71). As Kooser continues we see that the individual is not reading the stone but is focused on the life and death of insects invisible to others ("Instead I had found in its perfect web a handsome black and yellow spider pumping its legs to try to shake my footing as if I were a gift, an enormous moth that it could snare and eat"). Reading poems can be used in conjunction with other teaching techniques. For example, asking students to make sketches of elders is another way to draw attention to their assumptions about the elderly (Barrett \& Cantwell, 2007). In listening to Kooser's poem and drawing sketches of the elderly students are less likely to deny their own stereotypes.

Another topic of class discussion that may involve confronting one's assumptions about aging is an interesting paradox about aging and subjective well-being. While older adults tend to have more objective hardships and losses as compared with younger adults, they do not report lower levels of happiness (Lacey, Smith \& Ubel, 2006). This counter-intuitive research pattern can be explored with a variety of songs and poems so that students can hear the voices of older adults explain how they have coped with their lives and managed to experience satisfaction too. Optimally, the varied explanations revealed in the lyrics and poems can be linked to different theoretical explanations noted in the course textbook or empirical articles. For example, in the Beatles' (1967) song, When I'm sixty-four, it is clear that there is an 
expectation that with age comes accommodation (i.e., simple pleasures such as "Sunday mornings go for a ride" supersede the thrills of youth) and new benefits arise over time ("grandchildren on your knee"). Other songs and poems can also be used to address other aspects of this paradox. For example, in Patty Griffin's (2002) song, Making Pies, the central figure could be described as one who is modestly satisfied with her life and has adjusted to loss by doing her work, in this case making pies, staying close to family and volunteering at her church. The listener also hears that she has shifted her expectations and no longer worries about wearing a plastic cap while she works since her hair is now gray.

Almost any unit in a course on aging could benefit from discussing one or more poems or songs even if it is not used consistently throughout the course. Whenever poems and songs are used the possibility of transforming facts and theories into memorable and coherent life portraits occurs. This can help to convey ideas that may be uncomfortable for students. Students can also see the value of other people's lives and better recognize their own stereotypes about aging. In conclusion, playing music with lyrics and reading poetry in a college class on aging can promote thoughtful reflection and discussion about issues students may otherwise resist.

\section{Acknowledgements}

I would like to thank Patti Russo who recommended numerous poem and song ideas and Molly DiSario who recommended several contemporary songs to be included.

\section{References}

Barrett, A. E., \& Cantwell, L. E. (2007). Drawing on stereotypes: Using undergraduates' sketches of elders as a teaching tool. Educational Gerontology 33, 327-348.

Bowman, T. (2007). Poetry anthologies of grief and bereavement: A critical and applied review. fournal of Poetry Therapy 20, 219-223.

Collins, B. (2004). Sailing alone around the room. New York: Random House.

Conner-Greene, P. A., Young, A., Paul, C., \& Murdoch, J. W. (2005). Poetry: It's not just for English class anymore. Teaching of Psychology 32, 215-221.

Daehler, M. W., \& Miller, K. E. (2004). Themes and principles of child development illustrated in music. Teaching of Psychology 31, 195-197.

Furman, R. (2005). Using poetry and written exercises to teach empathy. Fournal of Poetry Therapy 18, $103-110$.

Green, M. (2004). Storytelling in teaching. APS Observer 17(4). (Retrieved June 1, 2007 from www.psychologicalscience.org/observer/getArticle.cfm?id $=1562$.

Green, R.J. (2003). Teaching psychology through film, video. APS Observer 16, 23-25, 28.

Griffin, P. (2002). 1,000 Kisses. ATO.

Kooser, T. (2004). Delights \& shadows. Port Townsend, WA: Copper Canyon Press.

Lacey, H. P., Smith, D. M., \& Ubel, P. A. (2006). Hope I die before I get old: Mispredicting happiness across the adult lifespan. Fournal of Happiness Research 7, 167-182.

Leck, K. (2006). Teaching personality theories using popular music. Teaching of Psychology 33, 34-36.

Lyon, G. E. (1999). Where I'm from. New York: Absey \& Company.

MacRae, N., \& Pardue, K. T. (2007). Use of readers theater to enhance interdisciplinary geriatric education. Educational Gerontology 33, 529-536.

Masters, J. L., \& Holley, L. M. (2006). A glimpse of life at 67: The modified future-self worksheet. Educational Gerontology 32, 261-269. 


\section{N. Weinberger}

Meyerson, P. M. (2006). Using children's picture books as tools to facilitate undergraduates' learning. College Teaching 54, 259-262.

Nelson, T. D. (2005). Ageism: Prejudice against our feared future self. Fournal of Social Issues 61, 207-221.

Paddock, J. R., Terranova, S., \& Giles, L. (2001). SASB goes to Hollywood: Teaching personality theories through movies. Teaching of Psychology 28, 117-121.

Powers, T. (2005). Engaging students with humor. APS Observer 18. Retrieved 29 July 2007 from http:// www.psychologicalscience.org/observer/getArticle.cfm?id $=1904$

Sarton, M. (1994). Coming into eighty. New York: W.W. Norton \& Company.

Schmidtke, C. R. (2000). Using a dramatic persona for a classroom life review. Educational Gerontology $26,447-465$.

Sweet Honey in the Rock. (1993). Still on the journey. Earthbeat.

The Beatles. (1967). Sgt. pepper's lonely hearts club band. Apple Corps.

Thomas, D. (1971). The poems of Dylan Thomas. New York: New Directions Publishing.

Warner, D. A. (2006). Empowering the older adult through folklore. Adultspan fournal 5, 91-100.

Weinberger, N., \& Russo, P. (2005). 75 Septembers: Facing issues of aging with music and poetry in the class and therapy group. Presentation at the New England Psychological Association annual meeting, Southern Connecticut State University, New Haven, CT.

Weinrauch, J. D. (2005). An exploratory use of musical metaphors to enhance student learning. fournal of Marketing Education 27, 109-121. 